\title{
PARENTAL CHILD ABDUCTION IN MALAYSIA: IS EVERYTHING RIGHT WITH OUR DOMESTIC LAWS?
}

\author{
Anis Shuhaiza Bt Md Salleh *
}

\begin{abstract}
Parental child abduction is an unacceptable and condemned act due to its bad implication caused especially on the child. Nevertheless, it was hard to charge parents for absconding or stealing their own child for a long accepted tradition and settled rule that both parents have equal rights over the child. Both would have justifications for their act to be considered as good and bad for the child even to the extent of abducting him or her from the other parent. However, as time passed, the laws particularly, family and criminal law, have also developed to face rapid changes in the family institution. The need to reform the laws for want of jurisdiction or lack of uniformity or adequacy of laws on a certain matter were among the result of the changes in family pattern. Experience from cases showed that it was very hard for any parent to get back his or her child once the subject has been brought outside the country. Thus, this article is aiming at scrutinising the domestic laws of Malaysia, particularly the family and criminal laws on parental child abduction as well as its enforcement aspect by referring to the relevant provisions and the decided cases. Suggestions are provided to strengthen the law and its enforcement aspect, being a tool to prevent parental child abduction.
\end{abstract}

Keywords: parental child abduction, domestic laws, enforcement, preventive tool

Lecturer, College of Law, Government and International Stiudies, Universiti Utara Malaysia (UUM), email: shuhaiza@uum.edu.my 


\title{
PEMELARIAN ANAK OLEH IBU BAPA DI MALAYSIA: ADAKAH SEMUANYA BAIK DI BAWAH UNDANG-UNDANG DOMESTIK KITA?
}

\begin{abstract}
ABSTRAK
Pelarian anak oleh ibu bapa merupakan satu perbuatan yang tidak dapat diterima dan dikutuk kerana kesan buruk daripadanya terutama ke atas kanak-kanak. Walau bagaimanapun, adalah sukar untuk mendakwa ibu bapa kerana membawa lari atau mencuri anak mereka sendiri disebabkan tradisi yang telah lama diterima dan peraturan yang telah jelas bahawa kedua ibu bapa mempunyai hak yang sama rata ke atas anak mereka.kedua-duanya mempunyai justifikasi sendiri berkaitan baik dan buruk untuk anak mereka walaupun sehingga membawa lari anak tersebut daripada ibu bapa yang lain. Namun, setelah masa berlalu, undang-undang terutamanya undang-undang keluarga dan jenayah turut berkembang untuk menghadapi perubahan yang cepat dalam institusi kekeluargaan. Keperluan untuk mengubah undang-undang kerana kehendak bidang kuasa, ketidakseragaman atau kecukupan undang-undang terhadap sesetengah perkara merupakan antara keputusan daripada perubahan bentuk keluarga. Pengalaman daripada kes-kes menunjukkan bahawa ia adalah amat sukar bagi mana-mana ibu bapa untuk mendapat semula anak mereka setelah anak tersebut dibawa keluar Negara. Oleh itu, makalah ini bertujuan untuk memperhalusi undang-undang domestik di Malaysia terutamanya undang-undang keluarga dan jenayah ke atas pemelarian anak oleh ibu bapa dan aspek penguatkuasaannya dengan merujuk kepada peruntukan undang-undang dan kes-kes yang diputuskan. Cadangan dibuat untuk memperkasakan undangundang dan penguatkuasaannya, sebagai satu alat untuk mencegah pemelarian anak oleh ibu bapa.
\end{abstract}

Kata Kunci: penculikan anak oleh ibubapa, undang-undang domestik, penguatkuasaan, alat pencegahan. 


\section{INTRODUCTION}

Parental child abduction is a phenomenon, ${ }^{1}$ which can only be curbed effectively with appropriate laws coupled with strong enforcement. Reliance will of course be on domestic laws in order to prevent and deal with acts of abduction before invoking any international instrument and cross border action, which are relatively more complex and time consuming. Taking into account that Malaysia is not a signatory state to any international instrument on this issue, particularly the Hague Convention on the Civil Aspects of International Child Abduction in 1980 or known as the Hague Convention on Child Abduction (HCCA), strong domestic laws and efficient enforcement agencies are seen as a must in order to prevent the occurrence of parental child abduction. Furthermore, the aim of the HCCA is not to determine a custody claim based on its merit but to remedy the wrongful removal of children from their existing homes. $^{2}$

Statistics obtained from the Crime Investigation Department, the Malaysian Royal Police Headquarter, Kuala Lumpur shows the existence of the act of parental child abduction. If the issue is not immediately curbed, it has the potential of turning into a huge national problem. This is because parental child abduction involves not only the personal fights between husband and wife but could very well leave an impact on the safety and diplomatic relationship between one country to another. It is said that even though the act does not involve the use of force, compulsion or deceitful means, it may in certain situations, involve indirect compulsion on the basis of a child parent relationship where a child will normally obey the instruction from either mother or father. ${ }^{3}$

Statistics show that there are 1,383 missing children aged below 18 years old from 2008 to 2010 . Among these cases, 53 are parental child abduction cases. More precisely, there were 13 cases in 2008,

1 Barbara E. Lubin, "International Parental Child Abduction: Conceptualizing New Remedies Through Application of the Hague Convention," 4 Wash. U. Global Stud. L. Rev. (2005): 415-445, accessed August 20, 2015, http://openscholarship.wustl.edu/law_globalstudies/vol4/iss2/8.

2 Suzana Muhamad Said and Shamsudin Suhor, "International Parental Child Abduction in Malaysia: Foreign Custody Orders and Related Laws for Incoming Abductions," Pertanika J. Soc. Sci. \& Hum. 20 (S) (2012): 101-110.

3 Suzana Muhamad Said and Shamsuddin Suhor, "Pemelarian Anak oleh Ibu atau Bapa Merentasi Sempadan”, 1 MLJ (2012): xxxix. 
24 cases in 2009 and 16 cases in 2010. More recently, out of 1,859 cases of missing children in 2011, 16 cases involved abduction by either father or mother. The figure on missing children increased to 2,193 cases in 2012 and out of them, 20 cases were caused by parental abduction. Nevertheless, these figures do not represent the actual cases of parental abduction based on the infringement of the court's order on custody of the child. This is because the statistics do not provide such a classification. Even though the figure does not reach hundreds as compared to other kinds of missing children, this is however an alarming rate and poses a real danger to the public and challenges our domestic laws.

\section{RELEVANT STATUTORY PROVISIONS PERTAINING TO CHILD ABDUCTION}

Parental child abduction is prohibited either directly or indirectly by family law statutes and also under the Penal Code and other related statutes. These include the Law Reform (Marriage and Divorce) Act 1976 (Act 164) (LRA), the Islamic Family Law (Federal Territories) Act 1984 (Act 303) (IFLA), the Penal Code (Act 574) and the Child Act 2001 (Act 611). This part will discuss the effect of the existing laws on the incidence of parental child abduction.

\section{(i) Law Reform Act/Islamic Family Law Act}

\section{Section 89 (2) (e) of the LRA / Section 87 (2) (e) of the IFLA}

Section 89 (2) (e) of the LRA / Section 87 (2) (e) of the IFLA provides for a condition that when the court awards a custody order, it may prescribe that the person to whom an award of custody is granted is prohibited from taking the child out of Malaysia. Despite its reference to the prohibition of parental child abduction directly, the implied intention of parliament in promulgating such prohibition is to promote the interest of the child in terms of getting access, contact and communication with the other non-custodial parent, which the child has been commonly with, prior to divorce. In the case of Teh Eng Kim v Yew Peng Siong [1977] 1 MLJ 234, the court held that the court would normally refuse to allow the children to be brought out of the jurisdiction, but for the welfare of the children the court might 
allow it. By considering the facts of the case, it is for the best interest of the children to be allowed to follow their mother to Australia. For want of love and affection, the children should not be ordered to remain in Malaysia with their father and stepmother.

The offence of parental child abduction would include the act of taking the child out of Malaysia in order to deny access or jeopardise the right of the non-custodial parent generally or the child particularly. This is done in breach of a Court order and should amount to an offence equal to that of parental child abduction. Understandably, the discretionary power of the court to prohibit the removal of the child out of Malaysia is only exercisable if, from the beginning, the court foresees that such removal is to be done in order to protect the child's welfare. Instead, it is done out of the personal or emotional influence of the person having the custody of the child to the extent of causing detriment and injustice to the child's welfare and the right of non- custodial parent, then it is justifiable for the court to prohibit it.

The very principle can be illustrated by the case of Foo Kok Soon $v$ Leony Rosalina ${ }^{4}$ where RK Nathan $\mathrm{J}$ stated that:

“...Section 89(2) of the Law Reform (Marriage and Divorce) Act 1976 ('the Act') provides that an order for custody may give a parent deprived of custody, the right of access to the child at such times and with such frequency as the court may consider reasonable. When access is granted to one parent, the effect is that the law recognises that the children should have the society or the company of their parent who does not have custody. It is in recognition of the parental right to reach out to their children that the court grants to one, custody and to the other, the right of access. The right of access is for the mutual benefit of both, the parent deprived of custody and for the children..."

More importantly, the custody order granted to one custodial parent is not to reward him or her and at the same time not to punish the other. Instead, it is to impose the responsibility specifically on a so called "more fit parent" after considering factors under the umbrella of the child's interest without ignoring the other party's rights and responsibilites towards the child.

4 [1998] 4 CLJ Supp 289, at 290 para 2. 
In other words, once the court has granted the orders for custody to one parent and access to another, each parent shall have the opportunity to exercise his or her right accordingly. Neither parties can deny the other's right nor attempt to deny it by using some unlawful tactics like bringing the child out of Malaysia on the pretext of providing the child with medical treatment, family visit or for a holiday. Such tactical actions aimed at denying the right of access may also amount to an act of "abduction" as the child is forbidden from having a relationship with the parent who was not given the right to custody. This goes directly against the main objective of the right to access, i.e. to ensure that the relationship between the child and his or her divorced parents is kept intact regardless of the parents' marriage breakdown.

\section{Section 101 of the Law Reform Act / Section 105 of the Islamic Family Law Act}

Another provision is section 101 of the LRA / Section 105 of the IFLA which enables the court to restrain any act of taking the child out of Malaysia upon the application of either the father or mother of a child or any interested person. This section is to ensure that the noncustodial parent does not take the child out of Malaysia unless leave is obtained from the court. This is inspired by sections 89 (2) (e) of the LRA and section 87 (2) (e) of the IFLA. Therein, the court may issue an injunction restraining the non-custodial parent from taking the child out of Malaysia or from giving unconditional leave for the said child to be taken out of Malaysia or the allowance of the act of taking the child may be subject to any condition or undertaking as the court may think fit. This may be done at the stage where any matrimonial proceeding is pending or under any agreement or order of the court, one parent has custody of the child to the exclusion of the other as decided in the case Shireen Chelliah Thiruchelvam $v$ Kanagasingam Kandiah [2010] 2 CLJ 736. In that case, Suraya Othman J, in allowing the Plaintiff's claims, had imposed the condition on the Defendant not to remove the three children from the Plaintiff's custody.

Similarly, in the case of Ong Kean Leong $v$ Tan Siew Hwa \& Lim Toh Seng (the Named Third Party), Kuala Lumpur (Family Court) Originating Summons No: F-24-29-2010, the Judicial Commissioner imposed a condition on the non-custodial parent (mother) not to bring 
the children out of Malaysia without the knowledge or permission of the custodial parent (father) as a matter of precaution. Such imposition is a discretionary power of the court if the court thinks fit to impose even though no evidence is adduced for the basis of the opinion or any clear fact found in the present case.

The Court however took an opposite view in the case of $\mathrm{Dr}$ Aparna Sehgal v Dr Jasmeet Singh A/L Sucha Singh, Kuala Lumpur (Family Court) Originating Summons No: F-24-58-2011. In that case, the Court took the opposite view and did not impose any condition on the non-custodial parent when she requested for permission to take the children out of Malaysia. This decision was made despite the high probability of the children being abducted as pleaded by the father. According to the judge, the allegation made by the father is a disputed fact and not a proven fact. The father had tried to convince the court that the mother was only using the excuse of taking the children out of the country in order to give one of the children eye treatment was only a disguise to allow her to abduct the children to India.

The subsequent provisions of section 101 (3) of the LRA and section 105 (3) of the IFLA provide that failure by the parties to comply with an order is punishable as an act of contempt of court. This can be illustrated by the case of Low Swee Siong $v$ Tan Siew Siew [2011] 9 CLJ 536 where the court held that the petitioner husband was in contempt of court by breaching the court orders to hand over the child or passport to the wife as ordered. The act of taking the law into his own hands regardless of the orders, led him to be punished for contempt of court as the court viewed imperatively, that the rule of law must be upheld.

The above discussion shows that although parental child abduction is recognised as an offence through decided cases, it is not yet specifically mentioned in the family law statutes. Even then, the prohibition is from taking the child outside the country without the permission or knowledge of the custodial parent. This prohibition only covers the act of parental child abduction across the border whilst still allowing the possibility of it happening within Malaysia. 


\section{(ii) Penal Code}

\section{Sections 359-361 of the Penal Code}

\section{Kidnapping}

Under the Malaysian criminal law, the offence of kidnapping as provided by section 359 of the Penal Code can be committed by anybody, that is either a stranger or parent. The use of the word "whoever" in sections 360 and 361 of the Penal Code would suggest this. Section 360 of the Penal Code provides for kidnapping from Malaysia. It states that:-

Whoever conveys any person beyond the limits of Malaysia without the consent of that person, or of some person legally authorized to consent on behalf of that person, is said to kidnap that person from Malaysia.

Meanwhile, section 361 of the Penal Code provides for kidnapping from lawful guardian. The section states that

Whoever takes or entices any minor under fourteen years of age if a male, or under sixteen years of age if a female, or any person of unsound mind, out of the keeping of the lawful guardian of such minor or person of unsound mind, without the consent of such guardian, is said to kidnap such minor or person from lawful guardianship.

These provisions do not specifically differentiate between an act done by a stranger or parent to entail a different punishment. As far as the punishment is concerned, section 363 of the Penal Code provides for imprisonment for a term, which may extend to seven years, and fine for whoever kidnaps any person from Malaysia or from lawful guardianship. By looking at the kind of kidnapping as stated by the Penal Code, be it kidnapping from Malaysia or from the legal guardian, it is not necessarily done pursuant to any other offence. In other words, the mere act of conveying, taking away or enticing of a child without a proper consent by itself is an offence. 
There are three elements for the first kind of kidnapping under section 360 of the Penal Code; kidnapping from Malaysia. They are:

(1) An act of conveying any person;

(2) The person must be brought across the border of Malaysia;

(3) No consent properly obtained from that person or other person who is legally authorised to consent on his or her behalf.

\section{Conveying}

What constitutes conveying for the purpose of this section is not defined therein. There must be an act of conveying any person regardless of gender, age and nationality. Notably, according to section 55A (1) of the Immigration Act 1959/63 (Act 155) (IA), what constitutes conveying a person to Malaysia for the purpose of the section is to include any involvement either directly or indirectly, by using any vehicle, vessel or aircraft contrary to the Act. While defining the word "transport" in drugs case, the court in Ong Ah Chuan v Public Prosecutor [1981] 1 MLJ 64 at 69-70, has used the words carrying or moving from one place to another as alternatives to the word conveying. In the instance case, Lord Diplock said that

In Their Lordship's view the immediate context of the verb 'transport', to which attention has been drawn, attracts the maxim noscitur a sociis which means 'it is known by the company it keeps'. This, and the fact that it appears in the definition of the verb to 'traffic', of which the natural meaning in the context of trafficking in goods involves dealings between two parties at least, and that the evident purpose of the Act is to distinguish between dealers in drugs and the unfortunate addicts who are their victims, all combine to make it clear that 'transport' is not used in the sense of mere conveying or carrying or moving from one place to another but in the sense of doing so to promote the distribution of the drug to another (emphasis added).

Thus, understandably, convey means to carry or move someone or something from one place to another by land, air or sea.

Across the Border of Malaysia

Furthermore, Article 1 of the Federal Constitution states that Malaysia or Federation comprises of thirteen states of Johor, Kedah, 
Kelantan, Malacca, Negeri Sembilan, Pahang, Penang, Perak, Perlis, Sabah, Sarawak, Selangor and Terengganu. It also includes the territories of the Federation that are the Federal Territory of Kuala Lumpur, Putrajaya and Labuan.

For the purpose of territorial limits, the provision indicates that it is sufficient for the offence to be complete when the person is taken out of the geographical limit of Malaysia. It means that the act of kidnapping is complete as soon as the boundary of the country is crossed even though the intended destination is yet to reach. ${ }^{5}$

Consent from the conveyed person or any legally authorized person One of the elements of criminality in conveying the person is the absence of consent from the person kidnapped or anybody who is eligible to consent on his or her behalf. Moreover, for the purpose of a valid consent, section 90 of the Penal Code is relevant. The consent given must not be given expressly or impliedly under any fear or misconception of fact. Normally, the person who kidnaps knows the fact about the fear and misconception of the person so consented. In other words, there shall be no threat or force for the consent, as submission indicates no valid consent.

Furthermore, the person so consented must be a person having sui juris or a person having full legal capacity to act on one's own. On the other way around, he or she shall not be a person who suffers from unsoundness of mind or intoxication which the nature and consequence of the consent are not understood by him or her. Besides, there shall be also no consent if a person under the age of twelve (12) years old gives it. Therefore, a male person aged fourteen (14) (or above) or female person aged sixteen (16) (or above) who willingly consents to such a conveying is not within this provision. The principle can be illustrated by the case of Ong On Hin $v$ Public Prosecutor [1990] 2 CLJ Rep 565; [1990] 1 CLJ 1176. In this case, the appellants claimed that he could not be said to have taken the girl away as she had left her parents' home on her own will and in fact, she herself went to meet the appellant and asked him to take her to Kuala Lumpur. By looking at the victim's age at that particular time, who was just fifteen years old, the court dismissed the appellant's claim. As the law sees that the girl below sixteen years old is

Hari Singh Gour, Wrongful Restraint, Wrongful Confinement Along with Criminal Force, Assault, Kidnapping, Rape and Unnatural Offences, (Allahabad: Law Publishers (India) Pvt. Ltd., 2006), 130. 
incapable to consent, the public interest demands that the appellant should be punished for seriousness of his act.

Similarly, if the consent is to be given by his or her lawful guardian, the same criteria for a valid consent must exist, otherwise, the consent so given will have no legal significance as the effect of this kind of consent is similar as if he himself or she herself has consented to the act.

Importantly, the consent can be given either before or after the conveyance, as the ratification of an act is also a consent, which has the same effect as previously give.

\section{Unrealised Custody Order or Unknown Custody Proceeding}

By referring to the above mentioned elements, a parental child kidnapping under this kind is possible when a parent brings his or her child outside Malaysia without the consent of the other custodial parent even though the parent who kidnaps does not realise about the order, which has already been granted. It can simply be said that in this situation, the person knows about the institution of the child custody proceeding but becomes unaware of the court's order on it. ${ }^{6}$ This situation can happen when a parent makes a unilateral movement of a child from the "child's ordinary resident" to another country without the other parent's consent or knowledge.

The case law to illustrate the situation is Herbert Thomas Small v Elizabeth Mary Small [2006] 6 MLJ 372. In this case, the plaintiff (husband) had taken his child to Malaysia without the defendant's knowledge and consent (wife). Three of them were all Australian citizens. The court viewed that all those material times, the plaintiff was fully aware of the Australian residency proceeding (equivalent to custody, care and control) by participating in filing affidavits in his defence. Therefore, the court observed that in kidnapping cases like this, it is in the child's welfare to be returned to its home country unless there is compelling reason to the contrary, or the child would suffer any harm if returned. Nevertheless, he or she will not be liable for the offence if the institution of the child custody proceeding was not made known to him or her.

On this matter, the act of parental child kidnapping (or parental child abduction) becomes an offence under the law of Malaysia when there is a written court order granting the right of custody of a child to

$6 \quad$ Hari Singh Gour,138. 
a particular party or the court order prohibiting the child to be brought outside Malaysia. $^{7}$

Elements of Kidnapping from Lawful Guardian

Section 361 of the Penal Code states that :

Whoever takes or entices any minor under fourteen years of age if a male, or under sixteen years of age if a female, or any person of unsound mind, out of the keeping of the lawful guardian of such minor or person of unsound mind, without the consent of such guardian, is said to kidnap such minor or person from lawful guardianship.

Generally, there are four elements of kidnapping under section 361 of the Penal Code namely:

(1) The act of taking or enticing by anybody;

(2) Any minor under the age of fourteen for male or under sixteen for female or any person of unsound mind;

(3) Out of the keeping;

(4) Without the lawful guardian's consent.

However, there is an exception. This section is inapplicable to the act of any person who in good faith believes himself to be the father of an illegitimate child or who in good faith believes himself to be entitled to the lawful custody of such child, unless such act is committed for an immoral or unlawful purpose. It is stated in the Exception to section 361 of the Penal Code.

\section{The Act of Taking or Enticing by Anybody}

The word taking or enticing is not defined by the Code. This provision is to be applied generally in the sense that it does not specify the relationship of person who commits and the victim, i.e.; whether he is a stranger or somebody known to the victim. It means that the act of taking or enticing can be done by anybody regardless of gender or relationship. Literally, the act of taking or enticing does not require the use of compulsion, force or even deceitful means to bring

Zanariah Noor, "Melarikan Anak ke Luar Negara: Kawalan Undang-undang di Malaysia dan di Bawah The Hague Convention on the Civil Aspect of International Child Abduction 1980," Jurnal Syariah, 18 No. 1137 - 162 (2010): 141. 
away the minor. This is highlighted by Buhagiar $\mathrm{J}$ in the case of Neelakandan v Public Prosecutor [1956] 1 MLJ 208.

For the purpose of this section, the will or consent of a minor is immaterial. In some instance, the minor may wilfully wish to follow the so-called kidnapper on whatever reason so long as it is done without the consent of lawful guardian. The constructive meaning of taking is discussed in the case of Ramasamy v. Public Prosecutor [1938] 1 MLJ 137 to include persuasion, blandishment or enticement. The court in Ramasamy's case has referred to the case of Rex $v$. Jarvis (1902) 20 Cox 249, on the meaning of "taking". In Jarvis's case, the word "taking" is defined in accordance to the provision of section 55 of the English Act, which provides that:

Whosoever shall unlawfully take or cause to be taken any unmarried girl, being under the age of 16 years out of the possession and against the will of her father or mother...

As such, Jelf $\mathrm{J}$. viewed that it is not necessary for an actual physical taking away of a girl to render conviction, it is sufficient if the prisoner (accused) persuaded her to leave her home or go away with him by persuasion or blandishments.

Furthermore, the word "taking" is highlighted by the court in the case of The People (at the Suit of the Attorney General) v Michael Edge (1) [1943] 1IR 115 at 148. In the instance case, Black J. stated that "taking" is always held to include a constructive taking so that the term kidnapping is wide enough to cover enticing away by fraud or by persuasion so long as it is done against the will of the parent or guardian.

In short, by referring to the fact of the case, "taking" is established if it can be shown that the accused personally and actively assisted the getaway of a person from the house of or from the custody of any person who was taking care of the latter or on behalf of the guardian. The principle has been highlighted by the Calcutta case of Janendra Nath Dey v Khitish Chandra Dey (1935) 39 CWN 1280. Nevertheless, in Janendra, the discussion on the meaning of "taking" was done in the light of section 498 of the Penal Code, which provides for enticing, taking away, or detaining with a criminal intent a married woman. Cussen J. in the local case of Ramasamy $v$ Public Prosecutor [1938] 1 MLJ 137 followed the principle. 
More significantly, a wider interpretation to the word "taking" has been given by Buhagiar J. in the case of Neelakandan $v$ Public Prosecutor [1956] 1 MLJ 208, when the court held that a mere leading of a not unwilling child is sufficient to constitute taking or enticing. It is also stated in the case of $R v$ Olifier (1866) 10 Cox 402, to include a person's inducement so as the victim acting upon it, comes to the inducer, albeit at an unexpected time, from which the inducement continues. In relation thereto, the court in $R v$ Miller (1876) 13 Cox 179, viewed that without such inducement, he is not bound to return the victim.

In addition, the court in Ong On Nin v Public Prosecutor [1990] 2 CLJ Rep 565; [1990] 1 CLJ 1176, held that in order to establish a case of for kidnapping from lawful guardianship under section 361 of the Penal Code, the prosecution must prove that the accused has taken some active steps, by persuasion or otherwise, to cause the victim to leave home. In this case, the court viewed that the appellant's conduct by systematically cultivating her trust, hence fascinating her into a relationship of innocent concern, constituted enticing for purposes of this provision. Accordingly, the appeal against conviction was dismissed.

Any minor under the age of fourteen for male or under sixteen for female or any person of unsound mind.

This is a self-explained provision where the minor's age for both male and female has been specifically prescribed therein. For purpose of this section, the act of taking or enticing excludes those who are beyond the stipulated age. Nevertheless, the age limit is inapplicable to any person with unsound mind mainly because such person is unable to understand the nature and consequences of the act.

Equally, the rationale behind the stipulated age is that it is very much related to the principle of consent as provided by law. This can be supported by the Explanation to section 376B of the Penal Code pertaining to incest. It states that a person who is under sixteen years of age, if female, or under thirteen years of age, if male shall be deemed to be incapable of giving consent.

\section{Out of The Keeping}

The distance or length of time for the minor being taken away from his or her lawful guardian is immaterial to constitute kidnapping under this section. The principle is enshrined in the judgment of 
Buhagiar J in the case of Neelakandan v Public Prosecutor [1956] 1 MLJ 208.

Similarly, it is immaterial whether the person so taking or enticing the minor has reached the destination or place where the minor had intended to be brought. Out of the keeping denotes out of the control, custody and supervision of lawful guardian or plainly construed as beyond which the guardian can keep eye on his or her minor.

This requirement is seen to be simple as physically absence of a minor from the lawful guardian because of taking away or enticing may constitute kidnapping but then it is so stern in the sense that such provision is promulgated in order to ensure the safety and interest of a minor as well as the lawful guardian. Besides, the court would give a wider interpretation to the word "keeping" in the sense that a girl, who has already attained puberty, is still regarded as within her father's keeping so long as she remained unmarried. Such interpretation is enunciated in the judgment of Briggs $J$ in the case of Omar Bin Haji Jaafar v Public Prosecutor [1952] 1 MLJ 94.

\section{Without the Consent of Lawful Guardian}

The substance of the offence under this section is that the act of taking away or enticing is done without the consent of the minor's lawful guardian. Buhagiar $\mathrm{J}$ in the case of Neelakandan $v$ Public Prosecutor [1956] 1 MLJ 208 viewed that consent here implies knowledge of destination of the minor and the purpose for which the minor is being taken away. For purpose of this section also, there are people who are regarded as lawful guardian of a minor justifying them to give consent for any matter concerning the latter.

According to the Explanation to section 361 of the Penal Code, it provides that the "lawful guardian" therein include any person lawfully entrusted with the care or custody of such minor or other person. The term lawfully entrusted is defined in such a way to include formal and informal entrustment of a minor to any person, agent or organization to have respective rights and responsibilities. The principle is highlighted in the case of Syed Abu Tahir a/l Mohamed Ismail v Public Prosecutor [1988] 3 MLJ 485.

In such a case, it is for the court to decide based on the facts of the case whether there is a lawful entrustment from word of mouth, course of conduct and surrounding circumstances to accord the meaning of lawful guardian as contained in the Explanation to section 
361 of the Penal Code. Significantly, the lawful guardian in this section denotes the lawful guardian of the person and not necessarily the guardian of the property.

By virtue of section 3 of the Guardianship and Infants Act 1961 (Act 351) (GIA), the lawful guardian of the person of an infant shall have the custody of the infant, and shall be responsible for his support, health and education. As far as the GIA is concerned, lawful guardians of the infant's person have been provided by the Act to include father and mother ${ }^{8}$ or any surviving parent, ${ }^{9}$ testamentary guardian, ${ }^{10}$ guardian for an orphan infant who is appointed by the court, ${ }^{11}$ as well as the Protector in the case of an abandoned infant. ${ }^{12}$ Accordingly, Section 2(1) of the GIA defines a Protector to include the Director General of Social Welfare, the Deputy Director General of Social Welfare, a Divisional Director of Social Welfare, Department of Social Welfare and the State Director of Social Welfare of each of the States including any Social Welfare Officer appointed under any law.

On the other hand, the Act is inapplicable to Muslims except where the Act has been adopted by the law of the state ${ }^{13}$. Therefore, Winslow $\mathbf{J}$ in the case of Deputy Public Prosecutor v Abdul Rahman [1963] 1 MLJ 213, ruled that the Muslim law on lawful guardian must be referred to in order to do justice to the facts of any particular situation.

\section{(iii) Child Act 2001}

Section 52 of the Child Act 2001

Section 52 of the Child Act 2001 is the only provision which specifically deals with parental child abduction. This section criminalises the act of any parent who brings or sends out a child, without proper consent from the lawful custodian of the child. ${ }^{14}$ It is to prevent the act of disagreement or disrespect to the court's order on

Section 5 of the GIA.

Section 6 of the GIA.

Section 7 of the GIA.

Section 8 of the GIA.

Section 8 A of the GIA.

Section 1 (3) (a) and (b) of the GIA.

"Parliamentary Debates, Representative," accessed September 10, 2013, http://www.parlimen.gov.my. 
custody of the child. Besides, it provides defences for the accused and criminal punishment for the offender. The section provides that :-

52. (1) Any parent or guardian who-

(a) does not have the lawful custody of a child; and

(b) takes or sends out a child, whether within or outside Malaysia, without the consent of the person who has the lawful custody of the child commits an offence and shall on conviction be liable to a fine not exceeding ten thousand ringgit or to imprisonment for a term not exceeding five years or to both.

(2) A person has lawful custody of a child under this section if he has been conferred custody of the child by virtue of any written law or by an order of a Court, including a Syariah Court.

Understandably, a non-custodial parent who takes or sends out a child within or outside Malaysia without the consent of a custodial parent commits an offence under the Child Act 2001. The act is criminally punished, which, upon the conviction, the offender is liable for a fine or to imprisonment or to both. The section goes further to provide that the lawful custody stated therein refers to the custody conferred by any written law or by the court's order, be it civil or Syariah court ${ }^{15}$. By virtue of the section, the existence of the court's order on custody of the child, either in the interim or main course of proceeding, is a prerequisite to the offence. If there is no court order, both parents are treated by the law as having equal rights over the child of which they are able to freely exercise their rights including to travel with the child anywhere within or outside Malaysia. More importantly, there must be an act of violation of the order by a noncustodial parent in taking or sending out the child. By looking at the provision of the section, the act of a non-custodial parent, which is considered to be in violation of the court's order, is not only confined to taking the child, but also to sending out. It means that the act covers the movement of a non-custodial parent himself with the child or he causes the others to send the child out of Malaysia.

\section{Defences}

Nonetheless, there can be a defence under section 52 (3) (a) (i) of the Child Act 2001 for an act of a non-custodial parent in taking away the

15 Section 52 (2) of the Child Act 2001. 
child with the belief that the other custodial parent consented or would have consented to the taking if the latter was aware of all the relevant circumstances.

Furthermore, by virtue of section 52 (3) (a) (ii) of the Child Act 2001, the law provides a kind of tolerance for the act of a noncustodial parent if he or she can satisfy the court that all reasonable steps to communicate with the other custodial parent have been taken but failed. Likewise, such an act of a non-custodial parent is not regarded as an offence under section 52 (3) (b) of the same if he or she has reasonable grounds to believe that the child is being abused, neglected, abandoned or exposed in a manner likely to cause the child physical or emotional injury. Similarly, the subsequent provision of section 52 (3) (c) furnishes a defence to a non-custodial parent who fails to get the consent because of the unreasonable refusal by a custodial parent although the latter was aware of all the relevant circumstances.

\section{ANALYSIS}

The court in Azman Abdul Talib v Suhaila Ibrahim [2004] CLJ 397 ruled that the court's power to commit a litigant to prison for noncompliance of an order ought to be exercised very carefully. The relevant rules and procedures should be strictly observed and followed. In view thereof, the court shall be very strict and careful in exercising its power to commit any parent prison as committing any parent prison when no harm is caused to the child is not something widely accepted in Malaysia. The court cannot simply punish any parent who fails to obey the court's order on the custody of the child. In other words, the law breaking for the custody order per se will not justify punishment.

Nevertheless, such a notion may lead to the possibility that the parent who disobeys a court order will not be dealt with by the law. Therefore, the non-custodial parent may very well take the risk to abduct the child regardless of any court order which puts a condition on that parent to only do so upon the consent of the custodial parent. Besides, the court's order on custody of the child especially the Syariah court's order may be taken as a family matter with a very limited effect on the parties only. The nature of the order which is 
very personal has no serious consequential effect like other orders given by the civil courts could also be the reason why it is taken lightly. If the order is coupled with serious sanctions such as the freezing of accounts in case of non-compliance, this might make the potential offenders take heed. Consequently, it is not able to serve as deterrence for any potential or repeated parental child abduction cases. In addition, although there are provisions in the Penal Code prohibiting a person from kidnapping and abducting, yet the provisions are unlikely to be applied to parental child abduction.

\section{CONCLUSION}

It is submitted that the existing domestic laws on parental child abduction are insufficient to cater to the problem both at the national and international levels. ${ }^{16}$ It is observed that by having the criminal provisions and defences in the Child Act 2001, the intention of parliament in punishing the act of parental child abduction cannot be properly carried out. Reliance must also be made to s. 361 of the Penal Code. Notably, such a reliance would not make the existing provisions on kidnapping or abduction particularly the kidnapping by legal guardian redundant. Justifiably, by looking at the exception to section 361 of the Penal Code, ${ }^{17}$ the provision is only inapplicable to any person who in good faith believes himself to be the father of an illegitimate child. It is hoped that this will strengthen domestic laws and curb the incidences of parental child abduction in Malaysia.

16 Suzana Muhamad Said, "Pemelarian Anak oleh Ibu atau Bapa Merentasi Sempadan Malaysia: Satu Kajian Berdasarkan the 1980 Hague Convention on the Civil Aspects of International Child Abduction" (PhD diss., University Kebangsaan Malaysia, Bangi, 2012).

17 The Exception to section 361 states that this section does not extend to the act of any person who in good faith believes himself to be the father of an illegitimate child or who in good faith believes himself to be entitled to the lawful custody of such child, unless such act is committed for an immoral or unlawful purpose. 